\title{
A laboratory study of particle ploughing and pore-pressure feedback: a velocity-weakening mechanism for soft glacier beds
}

\author{
Jason F. THOMASON, ${ }^{*}$ Neal R. IVERSON \\ Department of Geological and Atmospheric Sciences, lowa State University, Ames, lowa 50011, USA \\ E-mail: thomason@isgs.uiuc.edu
}

\begin{abstract}
If basal-water discharge and pressure are sufficiently high, a soft-bedded glacier will slip over its bed by ploughing, the process in which particles that span the ice-bed interface are dragged across the bed surface. Results of laboratory experiments indicate that resistance to ploughing can decrease with increasing ploughing velocity (velocity weakening). During ploughing at various velocities (15-400 $\left.\mathrm{m} \mathrm{a}^{-1}\right)$, till was compacted in front of idealized particles, causing pore pressures there that were orders of magnitude higher than the ambient value. This excess pore pressure locally weakened the till in shear, thereby decreasing ploughing resistance by a factor of 3.0-6.6 with a six-fold increase in ploughing velocity. Characteristic timescales of pore-pressure diffusion and compaction down-glacier from ploughing particles depend on till diffusivity, ploughing velocity and sizes of ploughing particles. These timescales accurately predict the ranges of these variables over which excess pore pressure and velocity weakening occurred. Existing ploughing models do not account for velocity weakening. A new ploughing model with no adjustable parameters predicts ploughing resistance to no worse than $38 \%$ but requires that excess pore pressures be measured. Velocity weakening by this mechanism may affect fast glacier flow, sediment transport by bed deformation and basal seismicity.
\end{abstract}

\section{INTRODUCTION}

Resistance to basal movement of glaciers is usually thought to increase with slip velocity. This idea follows from classical sliding theories (Weertman, 1964; Nye, 1969; Kamb, 1970; Fowler, 1981) and is consistent with the widely applied empirical rule, $u=k \tau^{p} N^{-q}$, where $k, p$ and $q$ are positive constants, $u$ is sliding velocity, $\tau$ is basal shear stress and $N$ is effective pressure (the ice-overburden pressure minus the basal-water pressure (Paterson, 1994)). However, for the case of a hard bed, Schoof (2004) has extended the analysis of Fowler (1986) to show that, for randomly periodic bed roughness, slip resistance can decrease with increasing slip velocity, due to cavity growth in the lee of undulations and the resultant drowning of roughness elements. Decreasing slip resistance with increasing velocity is commonly called velocity weakening (e.g. Scholz, 2002, p. 83). During speedup of glaciers, it can focus the downslope component of glacier weight on parts of the bed not subject to velocity weakening or on the glacier sides, thereby contributing to further increases in speed.

Thus, an important question is whether soft beds, which are thought to more readily promote fast glacier flow and sediment mobilization (Clarke, 2005), are also susceptible to velocity weakening. Laboratory experiments indicate that till, probably the most common subglacial sediment, exhibits Coulomb-plastic behavior, such that its strength is independent of deformation rate and linearly dependent on effective normal stress (Kamb, 1991; Iverson and others, 1998; Tulaczyk and others, 2000). Minor velocity weakening was exhibited in the study of Iverson and others (1998), in which steady-state shear strength of two basal tills decreased by $\sim 1 \%$ per $100 \mathrm{~m} \mathrm{a}^{-1}$ increase in shear velocity. This is a small effect, however, and the observation that

*Present address: Illinois State Geological Survey, 615 East Peabody Drive, Champaign, Illinois, 61820 USA. some tills, rather than weakening, strengthen by similarly small amounts with increasing deformation rate (e.g. Tika and others, 1996; Tulaczyk, 2006) indicates that velocity weakening is not an intrinsic property of till.

Glaciers can also move over a soft bed by ploughing, the process in which particles embedded partway in the glacier sole are dragged across the bed surface (Brown and others, 1987; Alley, 1989; Iverson, 1999; Tulaczyk, 1999; Iverson and Hooyer, 2004). During this slip process the bed deforms locally near its surface in the vicinity of ploughing particles. The tendency for basal motion to be focused at or near the surfaces of soft beds when basal-water pressure is rising or high has been demonstrated in studies at a number of modern glaciers (Blake and others, 1994; Iverson and others, 1995, 2003, 2007; Engelhardt and Kamb, 1998; Truffer and Harrison, 2006). Ploughing is the most likely mechanism for this movement. When basal-water discharge and pressure are high, the water layer at the bed surface thickens, focusing shear stresses on fewer particles and increasing their likelihood of ploughing through the till bed, which is weakened by high pore pressure (Iverson, 1999; Iverson and others, 2007). Evidence of particle ploughing is common in the geological record from past and modern glacial environments (Fig. 1) (e.g. Clark and Hansel, 1989; Krzyszkowski, 1994; Jørgensen and Piotrowski, 2003; Christofferson and others, 2005; Piotrowski and others, 2006), and the size distribution of particles that have ploughed has been used to estimate the sliding speed of a past ice sheet (Iverson and Hooyer, 2004).

In this paper, we propose a velocity-weakening process associated with ploughing and test our hypothesis by pushing idealized particles through till with a large ringshear device. A pore-pressure feedback is demonstrated that reduces ploughing resistance as ploughing velocity increases in some tills. The data also highlight weaknesses of existing mechanical models of particle ploughing (Brown and others, 1987; Alley, 1989; Iverson, 1999; Tulaczyk 


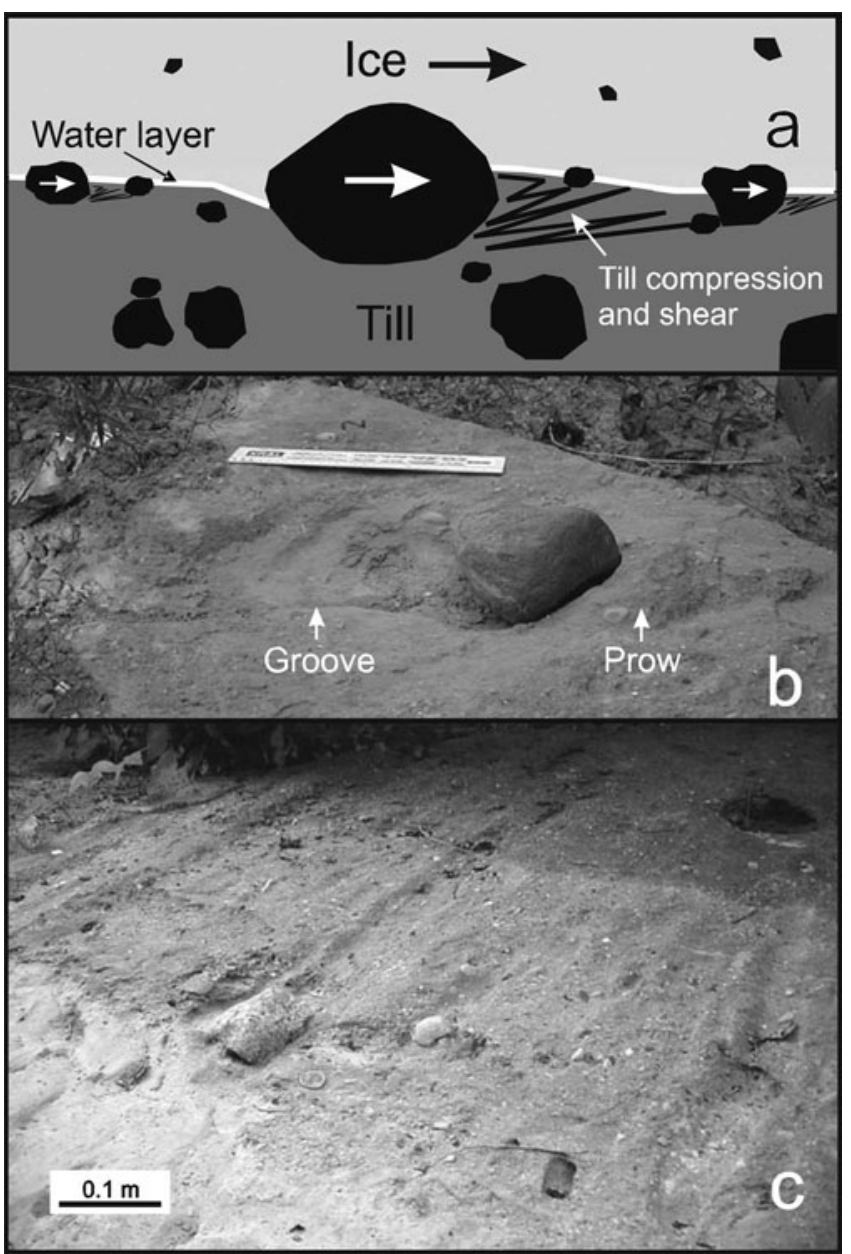

Fig. 1. (a) Ploughing particles at the ice-till interface. (b) Cobblesized clast (ruler is $0.3 \mathrm{~m}$ long) that has ploughed from left to right through Illinoian glacial sediments in central Illinois, leaving a groove up-glacier and a prow down-glacier (Iverson and Hooyer, 2004). (c) More evidence of ploughing (from upper right to lower left) at the same location.

1999) and provide the basis for a new model that incorporates pore-pressure feedback. This velocity-weakening mechanism could potentially promote fast glacier flow, focus motion at the bed surface and thereby inhibit pervasive bed deformation, and induce basal seismicity (e.g. Anandakrishnan and Bentley, 1993). The results are also relevant to ploughing on much larger scales: for example, ploughing by decameter-scale ice 'keels' on the bases of ice streams that may be responsible for submarine megalineations in glacier forefields (Tulaczyk and others, 2001; Clark and others, 2003).

\section{HYPOTHESIS: VELOCITY WEAKENING BY PLOUGHING}

Particles at the glacier sole that protrude partway into the substrate provide the roughness that couples a wet-based glacier to a soft bed. Slip at this interface requires some combination of ice movement past these particles by the classical sliding mechanisms (regelation and enhanced creep) and movement of the particles through the bed by ploughing. Clay, silt and fine sand particles at the bed surface that commonly constitute a large fraction of till will tend to be drowned in a water layer at the bed surface
(Brown and others, 1987; Alley, 1989; Iverson 1999; Tulaczyk, 1999). Thus, for typical till grain-size distributions the real area of contact between ice and larger particles at the bed surface is a small fraction of the bed area (Alley, 1989; Iverson, 1999), so shear stresses are focused on larger particles. When pore-water pressure is high, these particles plough due to the low strength of the till. Thus, resistance to basal motion, averaged over the surface of the till bed, can be limited by ploughing and can be too small to shear the bed at depth or result in much movement by the classical sliding mechanisms (Brown and others, 1987; Iverson, 1999). Also, if ice penetrates the till bed by regelation infiltration (e.g. Clarke, 2005), as has been observed in field experiments (Iverson and others, 2007), then grain-to-grain friction in the resultant debris-charged ice will inhibit movement of this ice over the soft bed by the classical sliding mechanisms. Thus, basal movement due to yielding of the till bed associated with ploughing is even more likely in this case than when debris in ice is sparse.

Consider particles of different sizes ploughing through the surface of a water-saturated till bed (Fig. 1a). Till that is down-glacier from ploughing particles is compacted and sheared as particles move through it. Porosity reduction during compaction increases the pressure on till pore-water. The low hydraulic permeability of many tills requires that this increase in pore pressure be large in order to generate the hydraulic gradient necessary to drive water out of the compacted zone at the rate that pores are shrinking. As first noted by Iverson and others (1994), the pore pressure in excess of the ambient pore pressure (hereinafter called the 'excess' pore pressure) should reduce effective stress in the bed down-glacier from ploughing objects, thereby reducing the till shear strength and the overall resistance to ploughing. Excess pore pressures are expected to increase with slip velocity, which will increase the ploughing speed and the rate of till compaction. Thus, as slip velocity increases, ploughing resistance will decrease. The magnitudes of excess pore pressure and velocity weakening will depend on the extent to which the rate of till compaction exceeds that of pore-pressure diffusion (Iverson and others, 1994; Iverson, 1999).

This velocity-weakening hypothesis is supported by field geotechnical studies in which an instrumented cone is pushed downward at constant speeds through watersaturated sediments. The resistance to movement of the cone decreases with both increasing penetration speed (Finke and others, 2001) and decreasing hydraulic permeability (Campanella and others, 1983). Pore-pressure measurements made adjacent to the cone demonstrate that these effects are due partly to excess pore pressures that weaken the sediment and decrease penetration resistance.

Some subglacial measurements are also consistent with this hypothesis. Rousselot and Fischer (2005) drove a steel rod, through a borehole, into subglacial till at Unteraargletscher, Switzerland, which ploughed through the till during sliding. The rod contained a sensor that recorded the till pore pressure down-glacier from the rod. Water-pressure fluctuations in the borehole and in the till were strongly correlated, but those in the till were systematically higher in amplitude. The authors argued that the higher amplitude was likely to be due to increased sliding speed, that caused more rapid till compaction down-glacier from the rod during periods of high basal-water pressure. Earlier measurements of the force on a ploughing rod at Unteraargletscher also indicated that 


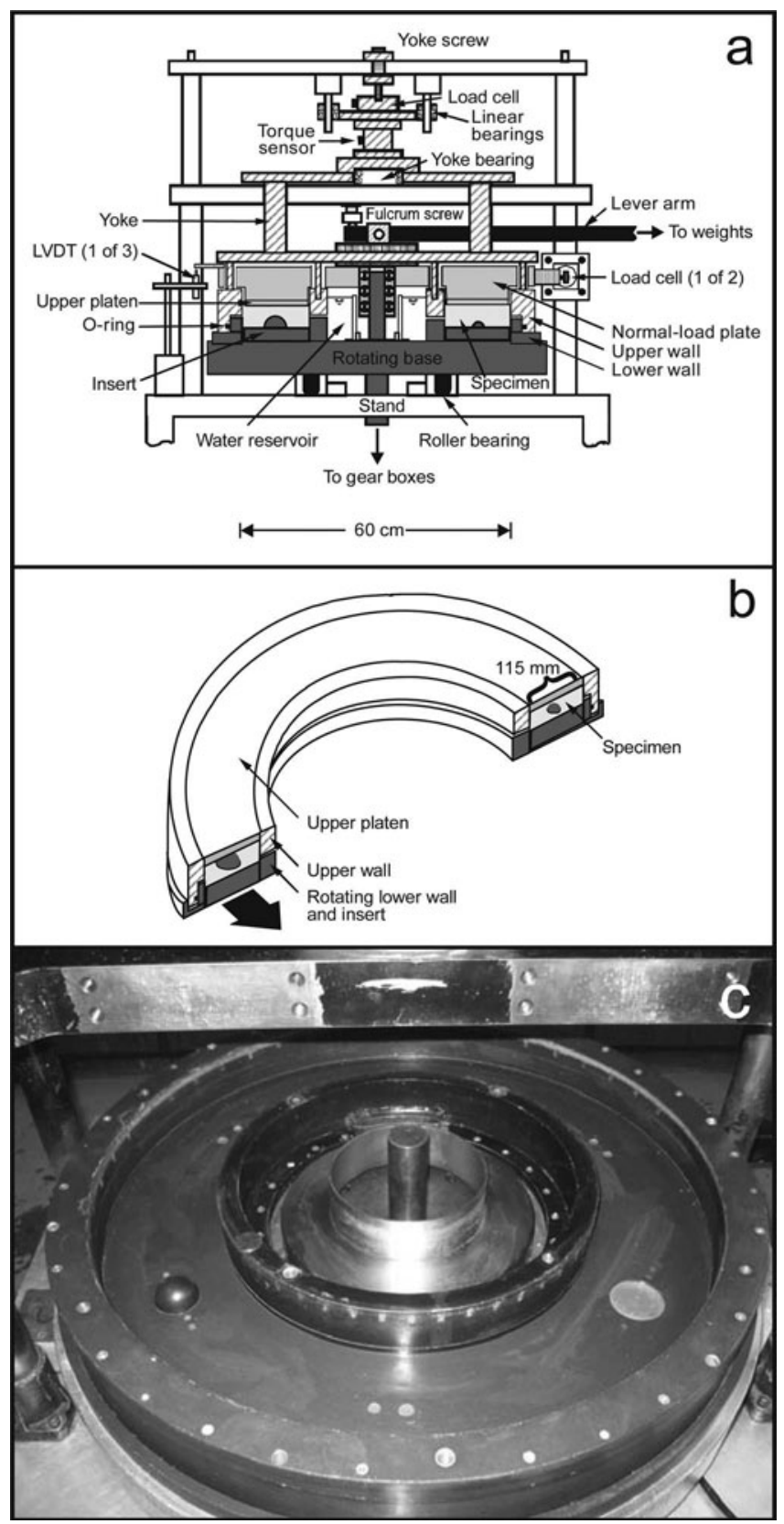

Fig. 2. (a) Cross-section of the ring-shear device, as adapted for ploughing experiments. Dark gray components rotate. (b) Detail of the specimen chamber with insert that contains the hemispheres. (c) Specimen chamber with only the large hemisphere visible at left.

ploughing resistance may have been reduced by excess pore pressures correlated to increases in glacier velocity (Fischer and others, 2001).

\section{METHODS}

Our aim was to study particle ploughing through till in the laboratory, measuring both pore pressure and ploughing resistance as a function of ploughing speed.

\subsection{Apparatus}

Our ring-shear device (Iverson and others, 1997) shears a remolded-till specimen to high strains under effective normal stresses similar to those beneath soft-bedded glaciers (Fig. 2a). This device has been used to study the mechanical properties of various tills (Iverson and others, 1998; Moore

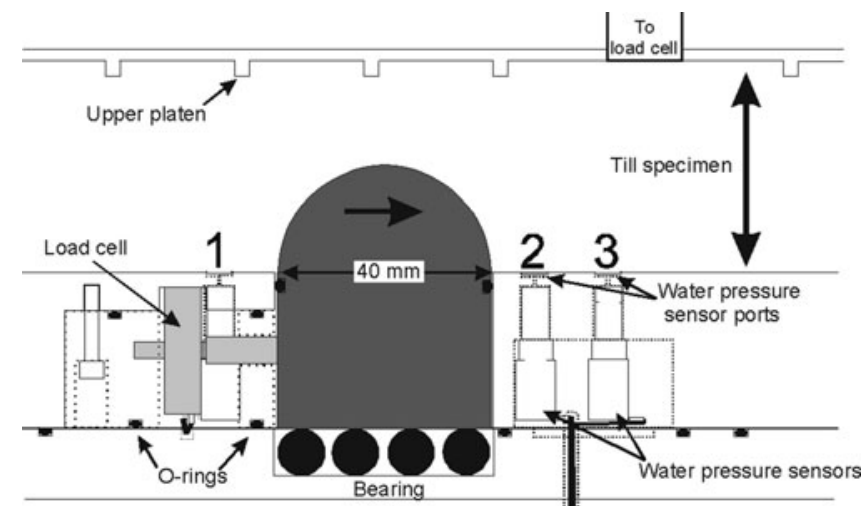

Fig. 3. Longitudinal cross-section of the specimen chamber in the vicinity of the large hemisphere. Movement direction of the hemisphere and adjacent insert is from left to right. The upper platen is fixed rotationally but can move up and down.

and Iverson, 2002), particle alignment with strain (Hooyer and Iverson, 2000a; Thomason and Iverson, 2006), mixing of granular materials in shear (Hooyer and Iverson, 2000b) and particle comminution (Iverson and others, 1996; Scherer and others, 2004). The specimen occupies an annular chamber that has an outside diameter of $0.6 \mathrm{~m}$ and a width of $0.115 \mathrm{~m}$, with a maximum specimen thickness of $0.08 \mathrm{~m}$. The water-saturated till specimen is hydraulically connected to an internal water reservoir exposed to the atmosphere, so water can move to and from the till if its volume changes. A normal stress is applied to the sediment by a lever arm with dead weights that presses down on a thick aluminum load plate. This plate is fixed rotationally but is free to move vertically if the specimen thins or thickens. The upper walls do not rotate and press against the rotating lower walls to minimize loss of specimen volume. Shearing displacement occurs along an O-ring that separates the upper and lower walls. An electric motor drives two gearboxes that turn the bottom platen at a constant speed.

The device was adapted to push ploughing clasts, idealized as hemispheres (19.0 and $40.0 \mathrm{~mm}$ in diameter), through water-saturated till to large displacements. The hemispheres extended above an aluminum insert that occupied the lower part of the specimen chamber and moved with the rotating base (Fig. $2 \mathrm{~b}$ and c). The surfaces of the hemispheres and insert were armored with a Teflon hard coat. Cylindrical extensions of the hemispheres were contained within the insert and rested on bearings (Fig. 3). Load cells within the insert recorded the bed-parallel forces exerted on the hemispheres in the direction opposite to that of ploughing. There were also pore-pressure sensors in the insert: two in front of and one behind each hemisphere. Water could escape from the till through the upper platen, which contains hundreds of $0.5 \mathrm{~mm}$ holes that connect to the internal water reservoir. A load cell located in the upper platen was used in some experiments to measure local stresses against the normal load plate as a hemisphere moved beneath it. This load cell recorded the force on a circular platen, $18 \mathrm{~mm}$ in diameter, which was mounted flush with the lower surface of the upper platen (Fig. 3).

The load cells that recorded the horizontal force on the hemispheres were calibrated in situ. This was necessary to account for friction in the bearings and compression of O-rings between the hemisphere and the aluminum panel 

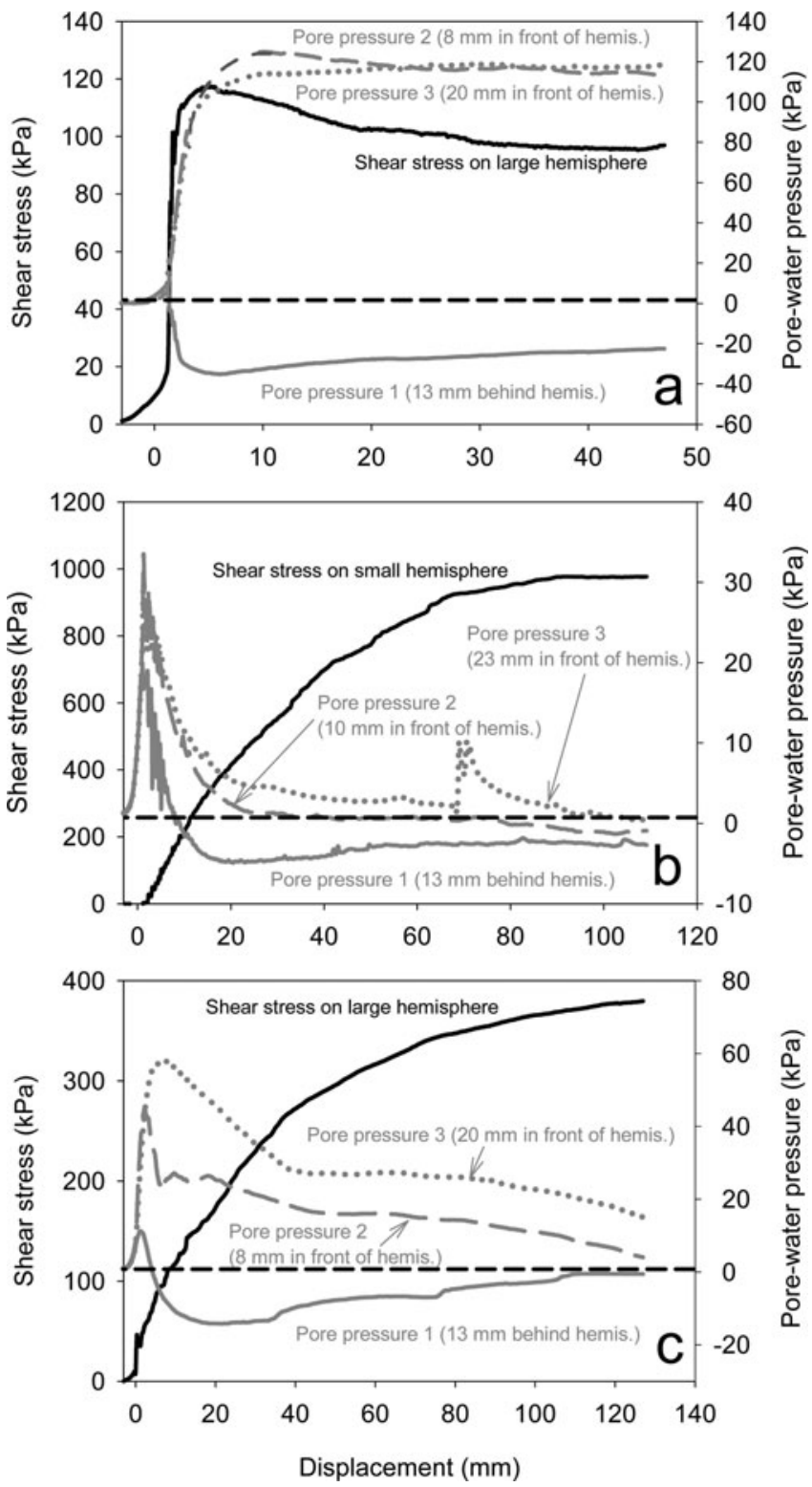

Fig. 4. Results of ploughing experiments with (a) large hemisphere and Des Moines Lobe till $\left(380 \mathrm{~m} \mathrm{a}^{-1}\right)$, (b) small hemisphere and Engabreen till $\left(50 \mathrm{~m} \mathrm{a}^{-1}\right)$ and (c) large hemisphere with Engabreen till $\left(50 \mathrm{~m} \mathrm{a}^{-1}\right)$. Dashed horizontal line indicates hydrostatic pore pressure $(\sim 0.5 \mathrm{kPa})$.

(Fig. 3), both of which supported some of the load exerted on the hemispheres by till. A cable was anchored to the hemisphere halfway up its face and was pulled under forces ranging from 0 to $200 \mathrm{~N}$. A downward force commensurate with a normal stress of $65 \mathrm{kPa}$, equal to the normal stress applied to the till during experiments, was applied to the hemispheres during calibrations. Calibration regressions were linear, with coefficients of determination $\left(R^{2}\right)$ greater than 0.98 .

\subsection{Procedure}

Six experiments were performed with each of two tills: a fine-grained basal till of the Des Moines Lobe (Alden Member) and a coarse-grained till from an end moraine of Engabreen, a valley glacier in Norway. These tills were chosen due to their contrasting grain-size distributions and hydraulic diffusivities (Table 1). When till is compressed in front of a ploughing clast, excess pore-pressure generation

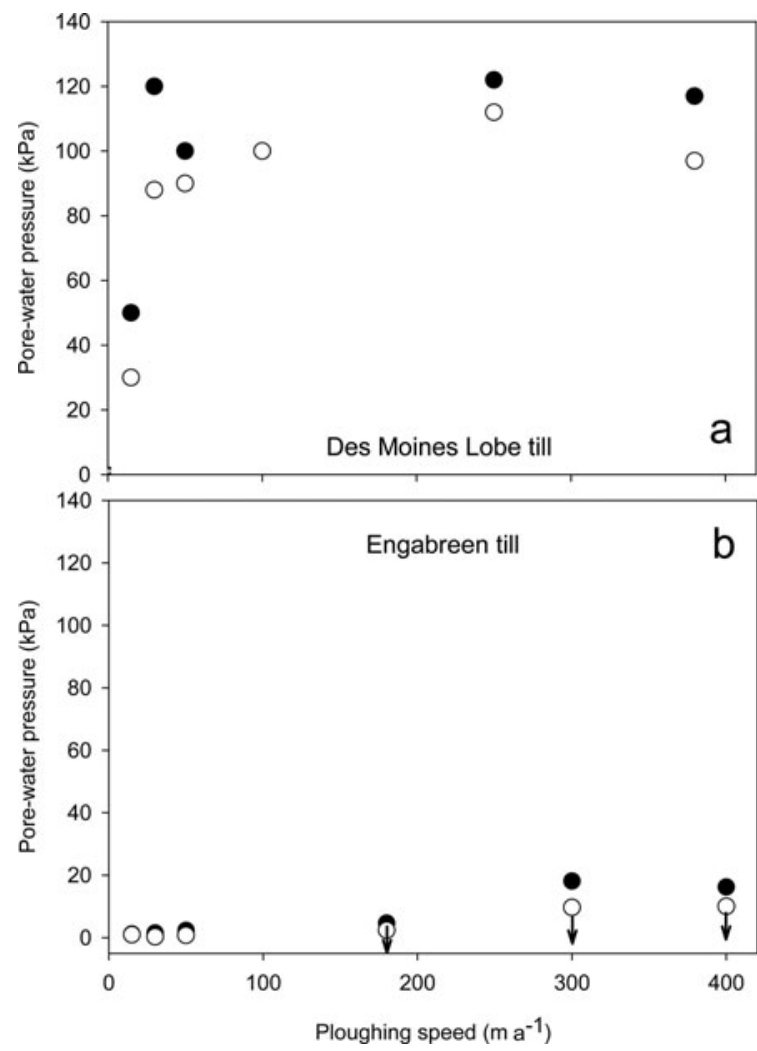

Fig. 5. Steady pore-water pressure in front of hemispheres (sensor 3 , Fig. 3) as a function of ploughing velocity for experiments with (a) the Des Moines Lobe till and (b) the Engabreen till. Each pair of data points at a particular speed represents results of one experiment, with open circle the small hemisphere and filled circle the large hemisphere. Arrows in (b) indicate that pore pressure was decreasing when the experiment was terminated.

depends on the hydraulic diffusivity of the till (Freeze and Cherry, 1979, p. 61), also called the coefficient of consolidation (Lambe and Whitman, 1969, p.407), which is proportional to the ratio of permeability to compressibility and is related to the grain-size distribution. Owing to its higher silt and clay fraction (Table 1), the Des Moines Lobe till is about 40 times less diffusive than the Engabreen till.

All particles $>5 \mathrm{~mm}$ in diameter $(10 \%$ of the smallest dimension of the sample chamber) were removed in accordance with standard geotechnical testing procedures (Head, 1989, p. 83). These particles, due to their scarcity (less than $5 \%$ of the till volume was removed), would have tended to have been surrounded by finer particles, so the effect of removing these large particles on either the till's internal friction or its permeability was probably small. This inference agrees with experience in geotechnical engineering that the fine fraction of poorly sorted sediments is primarily responsible for both their mechanical behavior (Mitchell and Soga, 2005, p. 432) and permeability (Mitchell and Soga, 2005, p. 256).

Remolded-till specimens were saturated with distilled water and added to the specimen chamber of the ring-shear device as a slurry. Prior to an experiment, the specimens were consolidated by applying a normal stress of $65 \mathrm{kPa}$ to the normal-load plate with the lever arm and dead weights. Consolidation was complete when excess pore pressure dissipated and specimen thinning had effectively ceased. The reduction in consolidation rate with time was used to 
determine hydraulic diffusivity using the square-root-of-time method (Das, 1998, p. 340) (Table 1). Vertical columns of wooden beads ( $4 \mathrm{~mm}$ diameter) were inserted in the till to assess the strain distribution near the hemispheres. In most experiments, at least three bead columns were placed across the path of each hemisphere $(30,58$ and $85 \mathrm{~mm}$ from the inner wall), and two columns were placed at far-field locations.

Experiments were conducted to displacements sufficiently large to allow steady-state drag forces and pore pressures to be approached. The hemispheres were pushed at speeds ranging from 15 to $400 \mathrm{~m} \mathrm{a}^{-1}$, similar to the sliding speeds of many glaciers (Paterson, 1994, p. 134). Each test was conducted under a total normal stress of $65 \mathrm{kPa}$, equal to that during consolidation and the same order as effective normal stresses measured beneath soft-bedded glaciers (e.g. Engelhardt and Kamb, 1997). In most experiments a quasisteady state was reached, in which rates of change in drag forces and pore pressures were small (roughly $\leq 3 \%$ per $10 \mathrm{~mm}$ displacement). Then ploughing was stopped, and the non-hydrostatic pore-water pressures developed during ploughing were allowed to dissipate. The normal stress was then removed from the till specimen, the device was disassembled and the distribution of strain around each hemisphere was determined by measuring the locations of the marker beads. In most cases, moisture content and porosity were measured prior to consolidation and after experiments were completed (Table 1).

\section{RESULTS}

During most tests shear stresses on the hemispheres (bedparallel drag force/plan-view area of hemisphere) increased rapidly upon initial displacement. Shear stresses then either peaked with a subsequent decline to a quasi-steady value (Fig. 4a) or, more commonly, they increased at a decreasing rate, asymptotically approaching a steady value (Fig. 4b and c). Pore pressures usually reached steady or quasi-steady values with sufficient displacement (Fig. $4 a$ and b). An exception occurred in experiments at high ploughing speeds with the Engabreen till, in which excess pore pressures were decaying toward hydrostatic values when experiments were terminated (Fig. 4c); at lower ploughing speeds with this till, pore pressures became nearly hydrostatic with sufficient displacement (Fig. 4b). Behind hemispheres, steady porewater pressures were usually slightly negative, reflecting suction (Fig. 4).

Magnitudes of steady-state pore-water pressures varied with ploughing speed and with till hydraulic diffusivity

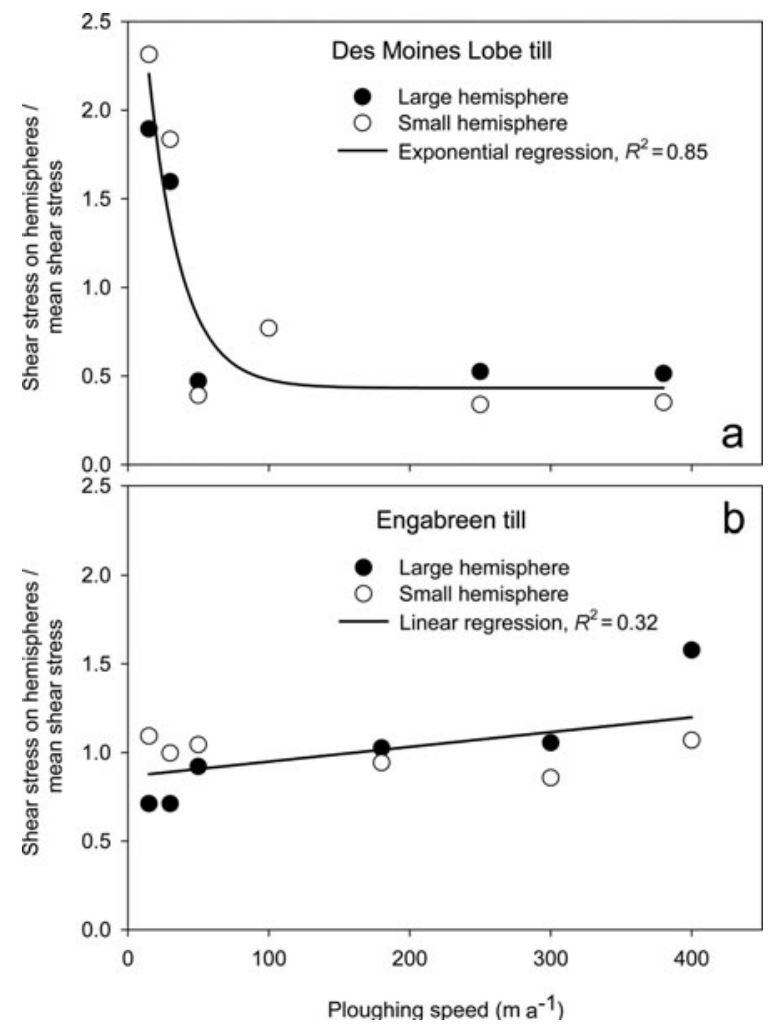

Fig. 6. Steady shear stress on hemispheres, normalized to the mean steady-state shear stress, for experiments with (a) the Des Moines Lobe till and (b) the Engabreen till. Each pair of data points at a particular speed represents results of one experiment.

(Fig. 5). In experiments with the Des Moines Lobe till, the magnitude of excess pore-water pressures in front of each hemisphere ranged from 30 to $122 \mathrm{kPa}$ and, in general, increased with increasing ploughing speed (Fig. 5a). Data from the large hemisphere during one experiment $\left(100 \mathrm{~m} \mathrm{a}^{-1}\right)$ were excluded because steady shear stresses were not approached during the test. Excess pore-water pressures observed in experiments with the more diffusive Engabreen till were significantly smaller, varying from 1 to $18 \mathrm{kPa}$ (Fig. 5b). Pore-water pressures in front of the large hemisphere tended to be slightly larger than those in front of the small hemisphere.

The effect of ploughing speed on steady-state shear stresses depended on till diffusivity (Fig. 6). Shear stresses in experiments with Des Moines Lobe till decreased exponentially with ploughing speed $\left(R^{2}=0.85\right)$, and by a factor of 3.0-6.6 over the full range of speed (Fig. 6a). In experiments

Table 1. Till properties and experimental conditions

\begin{tabular}{|c|c|c|c|c|c|c|c|c|c|c|}
\hline \multirow[t]{2}{*}{ Till } & \multicolumn{3}{|c|}{ Grain size } & \multirow[t]{2}{*}{ Friction angle } & \multirow[t]{2}{*}{ Cohesion } & \multirow{2}{*}{$\begin{array}{l}\text { Hydraulic } \\
\text { diffusivity }\end{array}$} & \multicolumn{2}{|c|}{ Pre-test } & \multicolumn{2}{|c|}{ Post-test } \\
\hline & $\begin{array}{c}\text { Sand } \\
\%\end{array}$ & $\begin{array}{l}\text { Silt } \\
\%\end{array}$ & $\begin{array}{c}\text { Clay } \\
\%\end{array}$ & & & & $\begin{array}{c}\text { Water content } \\
\%\end{array}$ & $\begin{array}{c}\text { Porosity } \\
\%\end{array}$ & $\begin{array}{c}\text { Water content } \\
\%\end{array}$ & $\begin{array}{c}\text { Porosity } \\
\%\end{array}$ \\
\hline Des Moines Lobe ${ }^{\dagger}$ & 52 & 32 & 16 & 18.5 & 4 & $8.7 \times 10^{-9}$ & $27.0 \pm 1.6$ & $\mathrm{n} / \mathrm{a}$ & $19.0 \pm 1.3$ & $32.2 \pm 1.8$ \\
\hline
\end{tabular}

*Hydraulic diffusivity calculated from consolidation data prior to ploughing experiments.

† Value of cohesion based on linear fit, but curvature of Mohr-Coulomb envelope at low normal stresses indicates near-zero value (fig. 5b of Clarke, 2005). 


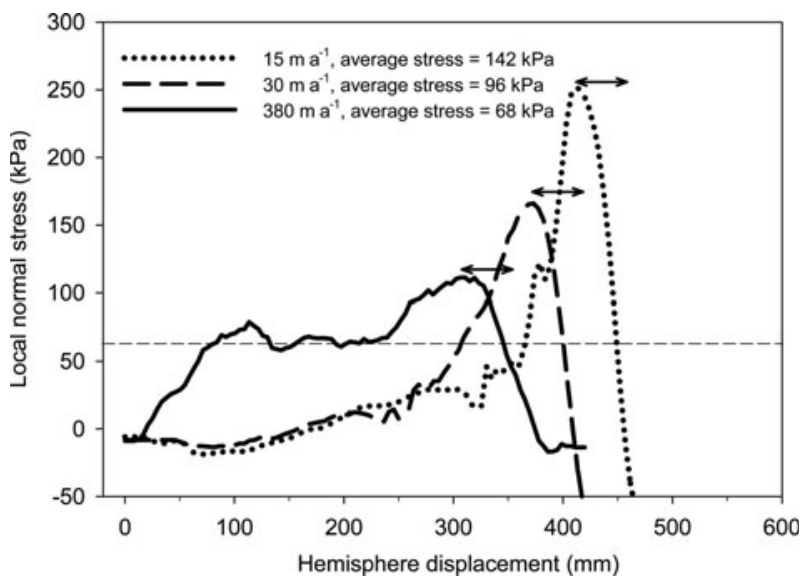

Fig. 7. Local normal stress (sensing face $18 \mathrm{~mm}$ in diameter) on the upper platen near the large hemisphere in experiments at three different ploughing speeds with the Des Moines Lobe till. Plots have been smoothed with a $4-5 \mathrm{~mm}$ running mean. Horizontal dashed line is the normal stress, averaged over the area of the upper platen. Lines with arrows at each end show the distance between where the peak local normal stress was measured and the top of the hemisphere.

with the Engabreen till, shear stresses on the hemispheres increased slightly with ploughing speed. However, linear regression of the Engabreen data yields a low coefficient of determination $\left(R^{2}=0.32\right.$ ) (Fig. 6b) and has power 0.49, well below that necessary to correctly describe the dependence on ploughing speed with greater than $95 \%$ confidence (0.8 (Cohen, 1988)). In contrast, the power of the regression of shear stress on ploughing speed for experiments with the Des Moines Lobe till (0.995) greatly exceeds that threshold.

The normal stress on the sensing face ( $18 \mathrm{~mm}$ in diameter) in the upper platen was also measured in three additional experiments using the large hemisphere and the Des Moines Lobe till (Fig. 7). This measurement was made as the hemisphere passed beneath the sensing face to assess the impact of the upper platen on the stress state and resultant strength of the till in front of the hemisphere. During these experiments, conducted at speeds of 15,30 and $380 \mathrm{~m} \mathrm{a}^{-1}$, the stress began to increase sharply when the leading edge of the hemisphere was, respectively, 120,150 and $350 \mathrm{~mm}$ from the load cell. In each case, peak normal stresses occurred $\sim 50 \mathrm{~mm}$ in front of the midpoint of the hemisphere (Fig. 7), comparable to the hemisphere diameter $(40 \mathrm{~mm})$. Peak stresses were 250, 165 and $110 \mathrm{kPa}$, respectively. Similarly to steady shear stresses on hemispheres in experiments with the Des Moines Lobe till, the magnitudes of the measured peaks in local normal stress were inversely correlated with ploughing speed.

Bead-displacement profiles (Fig. 8) indicated the formation of a till wedge in front of each hemisphere, which was immobile relative to adjacent till. This wedge was vertically and longitudinally more extensive in the Engabreen till. Upon excavation of the specimens after tests, a cavity with transverse dimensions nearly equal to those of the hemisphere was usually observed behind each hemisphere (Fig. 9a). This cavity was usually filled with soft, seemingly liquefied till. Cavities were elongate, forming a groove in overlying till that extended behind each hemisphere along the length of its path (Fig. 9b).
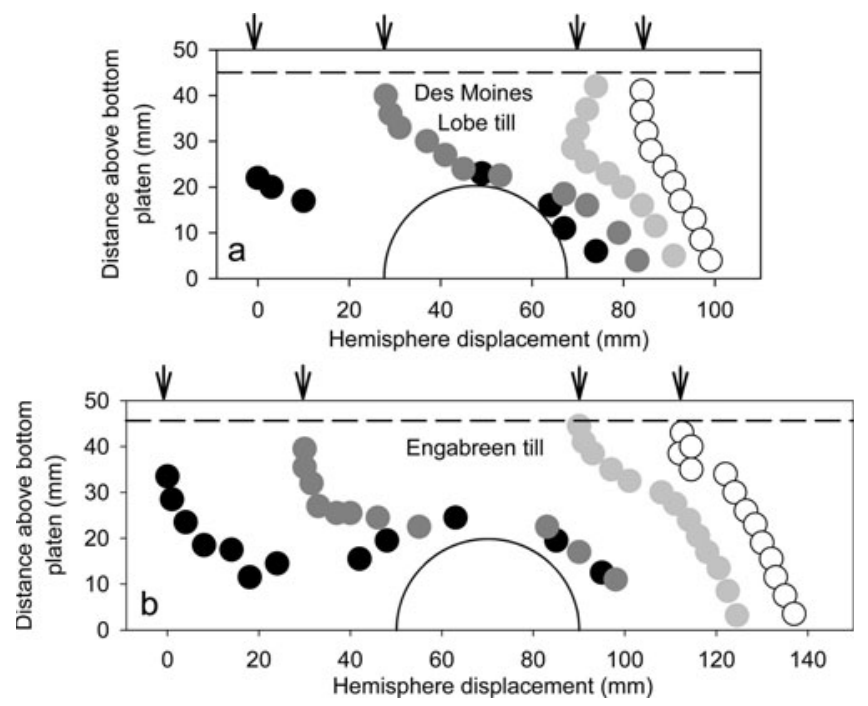

Fig. 8. Bead locations at the conclusions of experiments with the large hemisphere: (a) Des Moines Lobe till and (b) Engabreen till. Plots are at the same scales. Dashed line indicates top of till specimen. Arrows indicate locations of initially vertical bead profiles. Light gray beads in (a) were displaced prior to ploughing due to strain during consolidation.

\section{MODELING MEASURED SHEAR STRESSES}

An important question, owing in part to the likely effect of the sample-chamber boundaries on shear stresses, is whether measured shear stresses on the hemispheres can be reconciled with data and theory developed for the study of cone penetration through sediments. Theoretical models of cone penetration, in conjunction with cone-penetration data, are used routinely to estimate Coulomb frictional properties of sediments. The theory of Senneset and Janbu (1985) is most appropriate for our purposes because ploughing resistance is expressed in terms of effective stress. Also, the theory accounts for excess pore-water pressures that may be generated in sediments of low diffusivity, and it is reasonably applicable to different geometries, including a hemisphere.

For a hemisphere ploughing through water-saturated till, this theory indicates that the force on the leading edge of the hemisphere, $F_{\mathrm{s}}$, can be expressed as

$$
F_{\mathrm{s}}=A_{\mathrm{c}}\left[\left(N_{\mathrm{q}}-1\right)\left(p^{\prime}-\frac{c}{\tan \phi}\right)-N_{\mathrm{u}} u_{\mathrm{f}}+p\right],
$$

where $A_{c}$ is the cross-sectional area of the hemisphere normal to the ploughing direction, $p$ is the total normal stress, $p^{\prime}$ is the ambient effective normal stress in the till bed (equal to $p-u_{0}$, where $u_{0}$ is ambient pore-water pressure), $u_{\mathrm{f}}$ is excess pore-water pressure in front of the hemisphere, $c$ is cohesion, and $N_{\mathrm{q}}$ and $N_{\mathrm{u}}$ are dimensionless bearing capacity factors dependent upon the friction angle, $\phi$, of the till. If $u_{\mathrm{f}}=0$, then Equation (1) corresponds to fully drained conditions. The bearing capacity factors are defined as

$$
\begin{aligned}
& N_{\mathrm{q}}=\tan ^{2}\left(\frac{\pi}{4}+\frac{\phi}{2}\right) \mathrm{e}^{\pi \tan \phi} \\
& N_{\mathrm{u}} \sim 6 \tan \phi(1+\tan \phi) .
\end{aligned}
$$

Measurements from experiments with cones, piles and plates agree reasonably well with Equations (2) and (3) (Senneset and Janbu, 1985). Given that for a hemisphere of radius $r$, 

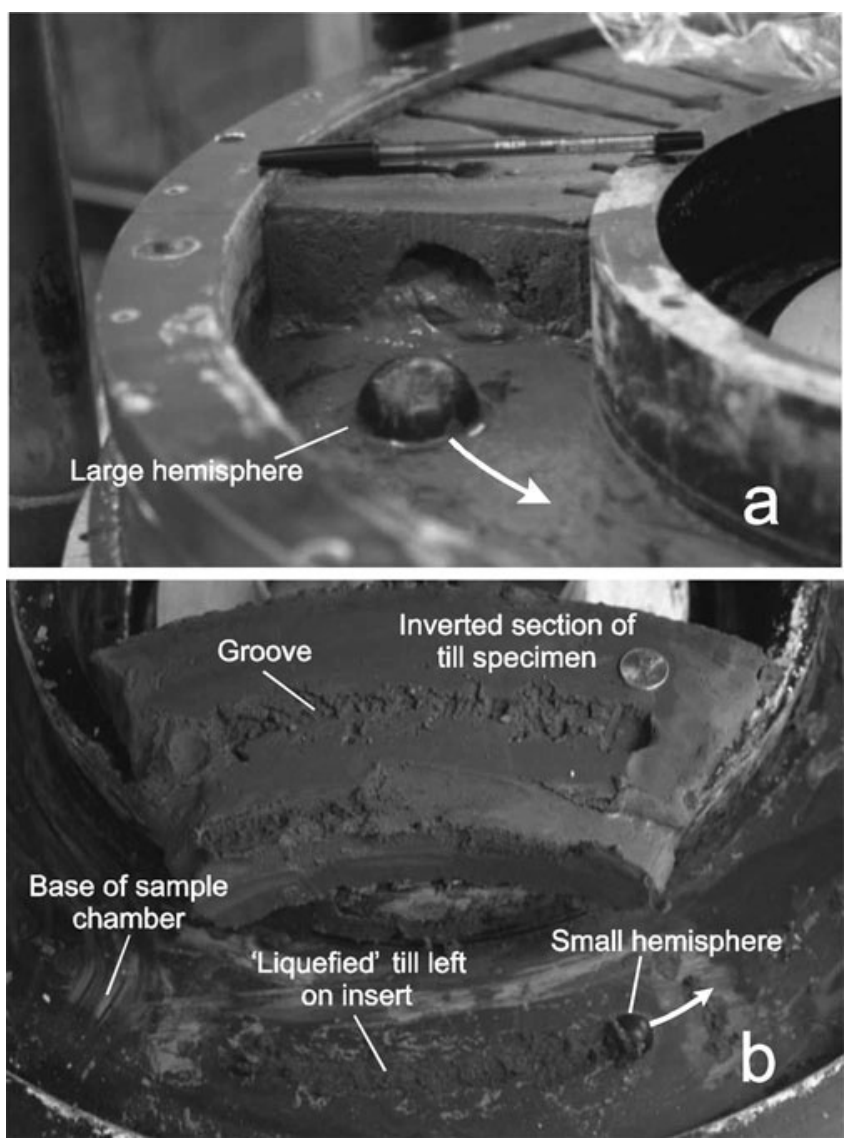

Fig. 9. (a) Cavity in Engabreen till behind the large hemisphere at the conclusion of an experiment. (b) Groove in the base of an inverted section of a specimen of Des Moines Lobe till, formed behind the small hemisphere (visible near bottom with seemingly liquefied till behind it).

$A_{\mathrm{c}}=\pi r^{2} / 2$ and the shear stress parallel to the ploughing direction is $\tau_{\mathrm{s}}=F_{\mathrm{s}} / \pi r^{2}$, the shear stress on a hemisphere is

$$
\tau_{\mathrm{s}}=\frac{1}{2}\left[\left(N_{\mathrm{q}}-1\right)\left(p^{\prime}-\frac{c}{\tan \phi}\right)-N_{\mathrm{u}} u_{\mathrm{f}}+p\right] \text {. }
$$

In addition to the drag associated with the shear strength of till, another component of drag arises due to the porepressure gradient around the hemisphere associated with pore-water flow in the direction opposite that of ploughing. This seepage-force effect is not included in the analysis of Senneset and Janbu (1985). In our experiments, excess porewater pressure was measured in front of and behind the hemispheres ( $u_{\mathrm{f}}$ and $u_{\mathrm{b}}$, respectively), so the component of water pressure parallel to the ploughing direction at any point along the surface of a hemisphere can be estimated as $\left(u_{\mathrm{f}}-k \theta\right) \cos \theta$, where $k=\left(u_{\mathrm{f}}-u_{\mathrm{b}}\right) / \pi$ (Fig. 10). The local surface over which this water pressure acts is $r^{2} \sin \theta \mathrm{d} \theta \mathrm{d} \alpha$. Thus, the local shear force is equal to $\left(u_{\mathrm{f}}-k \theta\right) \cos \theta r^{2} \sin \theta$ $\mathrm{d} \theta \mathrm{d} \alpha$. When this force is integrated over the surface of the hemisphere, the total shear force, $F_{\mathrm{w}}$ due to the excess porepressure gradient is expressed as

$$
F_{\mathrm{w}}=\frac{1}{2} \int_{0}^{2 \pi} \int_{0}^{\pi}\left(u_{\mathrm{f}}-k \theta\right) \cos \theta r^{2} \sin \theta \mathrm{d} \theta \mathrm{d} \alpha .
$$

Integrating Equation (5) twice and dividing the result by the area of the hemisphere, $\pi r^{2}$, yields the shear stress due to seepage drag, $\tau_{\mathrm{w}}$ :

$$
\tau_{\mathrm{w}}=\frac{1}{4} k \pi \text {. }
$$

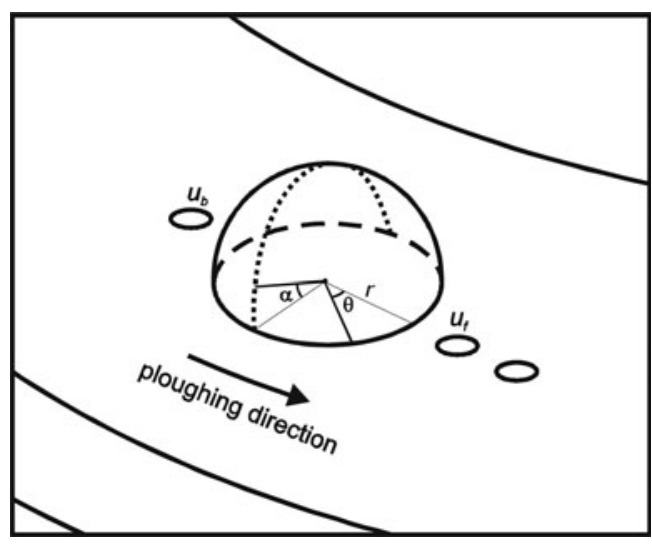

Fig. 10. Variables used for determining the seepage-related component of shear stress. The variables $u_{\mathrm{f}}$ and $u_{\mathrm{b}}$ are excess pore-water pressure at the locations indicated.

The total ploughing resistance, $\tau$, is the sum of the resistance due to the till shear strength (Equation (4)) and the seepage drag of water around the hemisphere:

$$
\tau=\tau_{\mathrm{s}}+\tau_{\mathrm{w}} .
$$

Application of this model to our results requires acknowledging that the boundaries of the sample chamber probably constricted till deformation past the hemispheres, thereby causing shear stresses on the hemispheres that were larger than in the absence of such boundaries. To approximately account for this effect, we used our measurements of local normal stress on the upper platen during the three experiments with the Des Moines Lobe till for which such data were available (Fig. 7). This stress, which was increased by the passage of the hemisphere due to the limited space for till deformation between it and the upper platen and walls, provides an estimate of total normal stress, $p$, as used in Equation (1). Thus we can compare calculated and measured shear stresses for these three experiments in which local normal stresses were measured. Total normal stresses used in the calculation were spatially averaged values determined by integrating the measured local stresses over the entire zone of influence as the hemisphere passed under the load cell (Fig. 7). The integrated values were 142, 96 and $68 \mathrm{kPa}$, for the three ploughing velocities $(15,30$ and $380 \mathrm{~m} \mathrm{a}^{-1}$, respectively).

Other parameter values for the calculation are presented in Table 2. Pore-pressure data used in the calculation were the steady values measured nearest to the hemisphere (at pressure sensors 1 and 2 in Fig. 3). Hydrostatic water pressure $(0.5 \mathrm{kPa})$ was used to calculate the ambient effective normal stress, $p^{\prime}$, required in Equation (4).

Shear stresses calculated from Equation (7) fall within 3\%, $38 \%$ and $27 \%$ of measured values for the experiments at 15 , 30 and $380 \mathrm{ma}^{-1}$, respectively (Fig. 11). We view this agreement as quite good, given that there were no adjustable parameters and the approximate way that the sample-chamber boundaries were factored into the calculation. The calculated fraction of the total shear stress due to seepage drag (Equation (6)) was no more than $0.34 \mathrm{kPa}$, so seepage drag was subordinate to the drag associated with the till strength. This observation accounts for the inverse relationship between the magnitude of excess pore pressures and ploughing resistance (Figs $5 \mathrm{a}$ and $6 \mathrm{a}$ ). 


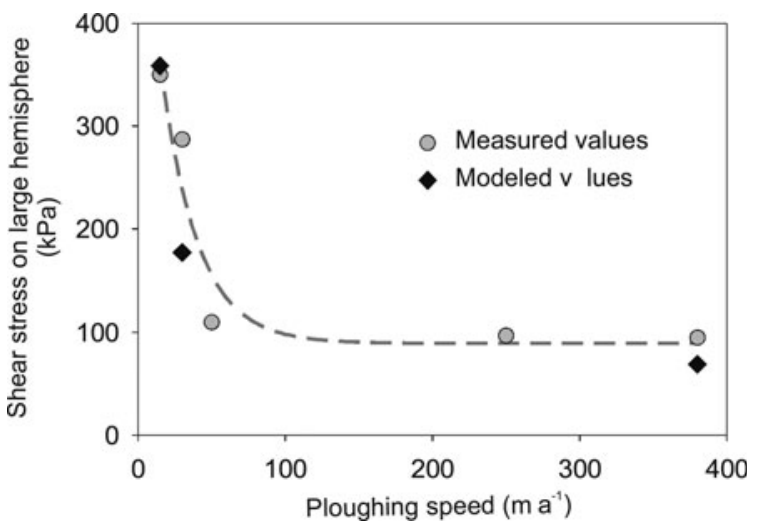

Fig. 11. Shear stresses on the large hemisphere in experiments with the Des Moines Lobe till compared with shear stresses calculated using cone-penetration theory and measured values of pore-water pressure, local normal stress (Fig. 7) and the friction angle of the till.

\section{DISCUSSION}

\subsection{Laboratory results}

These results demonstrate the pore-pressure feedback that can potentially cause velocity weakening at the surface of a soft bed and the dependence of this feedback on till properties. In experiments with the Des Moines Lobe till, there was a reduction in steady-state ploughing resistance by a factor of 3.0-6.6 over ploughing speeds ranging from 15 to $380 \mathrm{~m} \mathrm{a}^{-1}$ (Fig. 6a), and most of this reduction occurred over about a six-fold increase in velocity from 15 to $90 \mathrm{~m} \mathrm{a}^{-1}$. This weakening was caused by increases in excess pore pressure, driven by compaction of till in front of the hemispheres, which reduced the till shear strength (Fig. 5a).

Owing to the much higher hydraulic diffusivity of the Engabreen till, results of experiments with it were quite different. Excess pore-water pressures in front of the hemispheres were, at most, only $20 \%$ of those observed in the Des Moines Lobe till, and positive pore pressures were still decreasing when experiments at high speeds were terminated. Consequently, there was no convincing evidence of velocity weakening.

The shear stresses on the small hemisphere were generally larger than those measured on the large hemisphere: as much as 2.5 times larger with the Engabreen till (Fig. 4) and as much as $65 \%$ larger in the lowest-velocity experiments with the Des Moines Lobe till (Fig. 12). These differences are too large to attribute to pore-pressure effects alone. We speculate that these differences may be related to unmeasured local stress differences associated with the boundary effects of the sample chamber, but we lack sufficient data to provide a definitive explanation. Results for a given till and hemisphere illustrate velocity-dependent trends of shear stress and pore pressure that are generally consistent.

Deformation kinematics were also different for the two tills (Fig. 8). Strain was focused nearer the hemispheres in experiments with the Des Moines Lobe till. The Des Moines Lobe till has a lower friction angle $\left(18.5^{\circ}\right.$ (Hooyer and Iverson, 2002)) and contains more clay than the sand-rich Engabreen till $\left(32.0^{\circ}\right.$ (Moore, 2002)). This result is consistent with previous experiments with the ring-shear device in which strain in the specimen chamber was more localized in a clay-rich till than in a clay-poor till, reflecting, perhaps, either the tendency for clay minerals to align during shear and limit expansion of a shear zone (Iverson and others, 1997) or the tendency for shear-zone thicknesses in granular media to depend on grain diameter (Tulaczyk, 1999).

\subsection{Related laboratory data}

Geotechnical cone-penetration experiments in laboratory 'calibration chambers' demonstrate that excess pore pressures and speed-dependent reductions in ploughing resistance observed in our experiments with Des Moines Lobe till are in no way unique to the particular configuration of our experiment. In these experiments a rod with a cone-shaped end is pushed parallel to the rod axis at a constant speed through sediment contained in a chamber many times larger in diameter than the rod. The most illuminating experiments, to date, were conducted by Kim (2005). He used a calibration chamber with a diameter 106 times larger than the rod and measured both pore pressure immediately adjacent to the cone and the stress on the cone face (bearing resistance) required to push it at a constant speed through mixtures of clay and sand.

Results indicated a dependence of excess pore pressure and stress on the cone as a function of ploughing speed quite similar to that of this study (Fig. 12). Other experiments by Kim (2005) with slightly different mixtures of clay and sand and different shapes of ploughing elements yielded similar results. Moreover, the same inverse relationship between ploughing speed and resistance has been observed in many other geotechnical studies (e.g. Finnie and Randolph, 1994; Finke and others, 2001; House and others, 2001). Therefore, the excess pore pressures and velocity weakening we observed are unlikely to be artifacts of the particular design of our experiments.

The only laboratory ploughing experiments conducted with till, apart from those of this study, were those of Rousselot (2006) (see also Rousselot and Fischer, 2007), who

Table 2. Parameters used in model calculation

\begin{tabular}{|c|c|c|c|c|c|}
\hline \multirow[t]{2}{*}{ Parameter } & \multirow[t]{2}{*}{ Symbol } & \multirow[t]{2}{*}{ Unit } & \multicolumn{3}{|c|}{ Value for ploughing speed of } \\
\hline & & & $15 \mathrm{~m} \mathrm{a}^{-1}$ & $30 \mathrm{~m} \mathrm{a}^{-1}$ & $380 \mathrm{~m} \mathrm{a}^{-1}$ \\
\hline Friction angle & $\phi$ & $\circ$ & 18.5 & 18.5 & 18.5 \\
\hline Cohesion & $C$ & $\mathrm{kPa}$ & 0 & 0 & 0 \\
\hline Total normal stress & $p$ & $\mathrm{kPa}$ & 142 & 96 & 84 \\
\hline Effective normal stress & $p^{\prime}$ & $\mathrm{kPa}$ & 141.5 & 95.5 & 83.5 \\
\hline Excess pore-water pressure in front of hemisphere* & $u_{\mathrm{f}}$ & $\mathrm{kPa}$ & 30 & 81 & 114 \\
\hline Excess pore-water pressure behind hemisphere $^{\dagger}$ & $u_{\mathrm{b}}$ & $\mathrm{kPa}$ & 0 & -3 & -22 \\
\hline
\end{tabular}

${ }^{*}$ Values recorded from pore-pressure sensor $2 .{ }^{\dagger}$ Values recorded from pore-pressure sensor 1. 


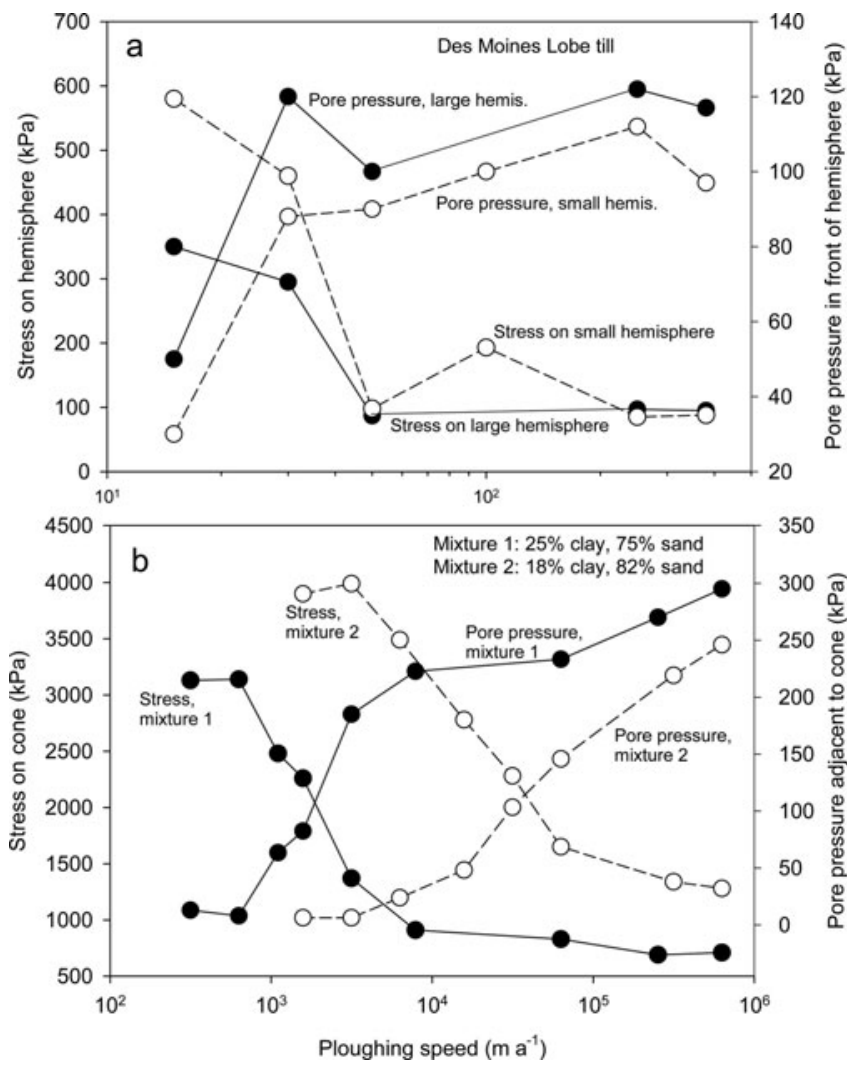

Fig. 12. (a) Shear stress on the hemispheres as a function of ploughing speed in our experiments with the Des Moines Lobe till. (b) Stress on the face of a cone, $11.3 \mathrm{~mm}$ in diameter, required to push it through two mixtures of clay and sand at various speeds in calibration-chamber experiments (from Kim, 2005).

used a customized apparatus to push a vertical rod horizontally through water-saturated till in a large chamber. These experiments approximated the action of a ploughmeter, an instrumented rod that can be driven into a soft bed through a borehole and used to study soft-bed mechanical properties (Fischer and Clarke, 1994). The force on the rod was measured at different ploughing speeds, and pore pressure was recorded at many locations around the perimeter of the rod. Although excess pore pressures in front of the rod increased with the rod speed, values did not exceed $\sim 15 \mathrm{kPa}$ and hence were as low as those measured with the Engabreen till (Fig. 5b). Ploughing velocities (365$6200 \mathrm{~m} \mathrm{a}^{-1}$ ) were about an order of magnitude higher than in this study, but particularly significant was the hydraulic diffusivity of the sediment used: $5 \times 10^{-5} \mathrm{~m}^{2} \mathrm{~s}^{-1}$. This value is approximately a factor of 140 and 5700 greater than that of the Engabreen and Des Moines Lobe tills, respectively (Table 1). No velocity weakening was observed. In the following section we show that the high diffusivity of the sediment used by Rousselot (2006) accounts for the low excess pore pressure measured in that study and the lack of velocity weakening.

\subsection{Conditions for pore-pressure feedback and velocity weakening}

The conditions under which excess pore pressure and velocity weakening are expected can be estimated by comparing characteristic timescales of compaction and pore-pressure diffusion in till down-glacier from a ploughing particle. If the latter exceeds the former, then pore-pressure

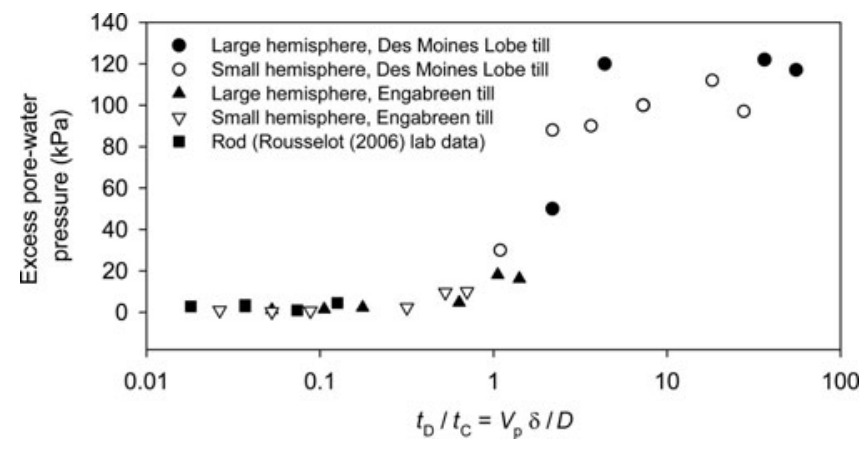

Fig. 13. Excess pore pressure as a function of $t_{\mathrm{D}} / t_{\mathrm{C}}$, the ratio of the characteristic timescales of pore-pressure diffusion and compaction, from the ploughing experiments of this study and from those of Rousselot (2006). Measurements from the latter study are from a sensor about one rod-diameter in front of the ploughing rod.

diffusion cannot keep pace with pore-pressure generation in the compacted zone, resulting in significant excess pore pressure and velocity weakening. The timescale for compaction, $t_{\mathrm{C}}$, is $\delta / V_{\mathrm{p}}$, where $\delta$ is the characteristic length scale over which the till compacts and $V_{p}$ is ploughing speed (Iverson, 1999). The value of $\delta$ was within $\pm 20 \%$ of the hemisphere diameters, as indicated by bead displacements in our experiments (e.g. Fig. 8). Geotechnical studies (Malyshev and Lavisin, 1974; Koumoto and Kaku, 1982) also indicate that the zone of sediment compaction in front of a ploughing object is roughly comparable to its diameter, so we consider $\delta$ to equal the hemisphere diameters. The characteristic timescale for pore-pressure diffusion, $t_{D}$, is $\delta^{2} / D$, where $D$ is the hydraulic diffusivity of the till (Iverson, 1999) and $\delta$ equals the length of the diffusion path. Thus,

$$
\frac{t_{\mathrm{D}}}{t_{\mathrm{C}}}=\frac{V_{\mathrm{p}} \delta}{D} .
$$

If $t_{\mathrm{D}} / t_{\mathrm{C}}>1.0$, significant excess pore pressure and velocity weakening are expected.

Figure 13 shows excess pore pressures measured in the two tills of this study and those measured in the glacial sediment used by Rousselot (2006), plotted as a function of $t_{\mathrm{D}} / t_{\mathrm{C}}$. Excess pore pressures are clearly correlated to conditions for which this ratio exceeds 1.0. This ratio was generally greater and less than 1.0, respectively, for experiments with the Des Moines Lobe and Engabreen tills, owing to the 40-fold difference in their diffusivities. Thus, only the Des Moines Lobe till exhibited clear velocity weakening (Fig. 6a). Although ploughing velocities in the study of Rousselot (2006) (see also Rousselot and Fischer, 2007) were about an order of magnitude higher than in this study, the much higher diffusivity of the sediment in that study (more than two orders of magnitude) results in $t_{\mathrm{D}} / t_{\mathrm{C}}<1.0$, which accounts for the low excess pore pressures (Fig. 13) and lack of velocity weakening observed in that study.

Having established that timescales for compaction and pore-pressure diffusion provide an effective means of estimating the conditions under which velocity weakening is expected, we can use these timescales to explore glacially relevant ranges of parameter space over which velocity weakening will occur. Setting the two timescales equal allows a transitional ploughing velocity, $V_{\mathrm{t}}=D / \delta$, to be defined, above which there will be significant velocity weakening. We again consider $\delta$ to be equal to the particle 


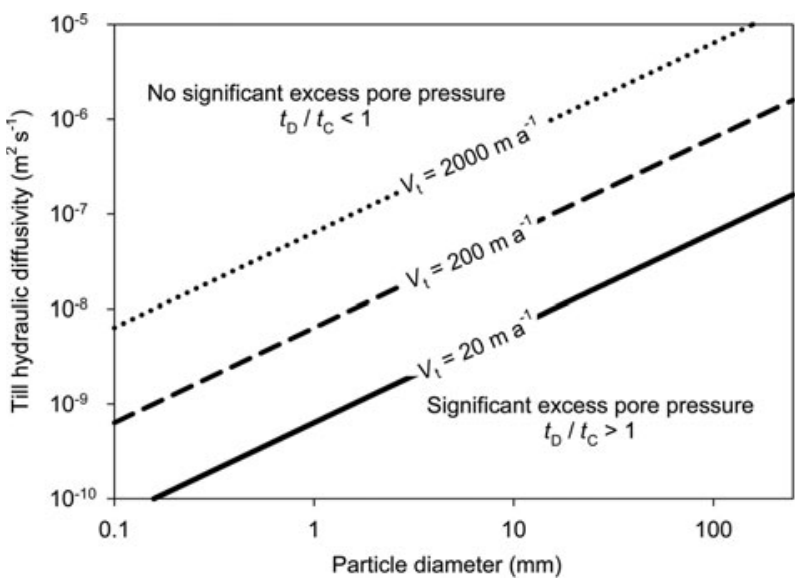

Fig. 14. Ranges of till diffusivity and sizes of ploughing particles over which significant excess pore pressure and velocity weakening will occur for different transitional glacier slip velocities, $V_{t}$, for which $t_{\mathrm{D}} / t_{\mathrm{C}}=1$.

diameter and additionally acknowledge that ploughing speeds will be less than, but commonly comparable to, the slip velocity of ice over the till surface (Iverson and Hooyer, 2004; Iverson and others, 2007), particularly when till is weak and ploughing resistance is low. If we, therefore, equate ploughing velocity with slip velocity, ranges of till hydraulic diffusivity (Freeze and Cherry, 1979, p. 29, 55) and sizes of ploughing particles can be defined over which velocity weakening will occur for a particular slip velocity.

Figure 14 indicates that excess pore pressures and velocity weakening are expected over a wide range of slip velocity, till diffusivity and ploughing-particle size. Thus, activation of this velocity-weakening mechanism might occur over an increasing fraction of a soft bed as a glacier increases its sliding speed due to, for example, changing basal hydrology.

\subsection{Experimental deviations from the subglacial system}

The most obvious difference between these experiments and ploughing in a subglacial setting is the lack of ice flow past ploughing particles. This flow, by regelation and creep past particles at a speed proportional to the ploughing resistance, will result in a zone of reduced total normal stress downglacier from particles. The resultant reduction in effective stress on the bed there reduces the local till strength and ploughing resistance (Brown and others, 1987; Iverson, 1999). The effect is small, however, because for most particle sizes at the ice-bed interface, bed-parallel regelation will be the dominant ice-flow mechanism (e.g. Iverson, 1999). The theory of Nye (1967) then predicts a reduction of total normal stress on the bed down-glacier from ploughing particles of only $\sim 10 \%$ (Brown and others, 1987). Also, if regelation infiltration of the bed occurs (Clarke, 2005), as has been observed subglacially with resultant ice-cemented till overlying a soft bed (Iverson and others, 2007), bed-parallel ice flow past ploughing particles will be inhibited by frictional interaction among grains in the ice-cemented layer.

Pore-water drainage in our experiments must also be considered. In the ring-shear device, the permeable upper platen of the sample chamber (Fig. 3) is the single boundary where drainage of pore-water could occur. Its close proximity to the hemispheres $(\leq 50 \mathrm{~mm})$ is likely to have limited the timescale for diffusion and the magnitude of excess pore pressures.

Finally, the close proximity of the upper platen and walls of the specimen chamber to the hemispheres caused the strength of till near each hemisphere to be larger than would be the case subglacially. In applying cone-penetration theory (section 5), the effect of the upper platen was accounted for approximately by measuring the local total normal stress near the hemispheres (Fig. 7). Considerable supporting geotechnical data (section 6.2) indicate that this boundary effect did not obscure the relationships between ploughing speed, excess pore pressure and ploughing resistance that these experiments were designed to explore.

\section{IMPLICATIONS}

\subsection{Ploughing models}

No model of subglacial ploughing accounts for the porepressure feedback and velocity weakening observed in these experiments. Models that consider till a viscous or viscoplastic fluid (Alley, 1989) predict velocity strengthening during ploughing and are not supported by our results. Other models make the more experimentally tenable assumption that till behaves as a Coulomb-plastic material but neglect the pore-pressure feedback. The models of Brown and others (1987), Iverson (1999) and Iverson and others (2007) are strictly applicable to only the so-called drained case, in which till is sufficiently diffusive or sliding velocity is sufficiently small that significant excess pore pressures do not develop. The ploughing model of Tulaczyk (1999), in contrast, is strictly applicable to only the undrained case, in which till diffusivity is sufficiently small relative to sliding speed that there is effectively no pore-pressure dissipation. Tulaczyk calculated that ploughing resistance should differ between these two cases by a factor of 2.1-3.9. Our results (Fig. 6) and those of Kim (2005) (Fig. 12b) demonstrate reductions in ploughing resistance moving from largely drained to undrained conditions that are comparable.

Our new ploughing model (section 5) includes excess pore pressures and their effects on both till strength and seepage drag. Predictions of ploughing resistance with no adjustable parameters were within, in the worst case, 38\% of measured values over a wide range of ploughing speeds and excess pore pressures. The primary limitation of the model is that pore pressure needs to be measured independently. Computing steady pore-pressure distributions near particles using ploughing speed, sizes of ploughing particles and till hydrological properties would be an important next step in modeling ploughing.

\subsection{Glacier flow and sediment transport}

Basal motion tends to be focused near the surface of soft beds when basal-water pressure is high (Blake and others, 1994; Iverson and others, 1995, 2003, 2007; Engelhardt and Kamb, 1997; Truffer and Harrison, 2006), indicating that, when the bed is especially weak, ploughing, rather than the classical sliding mechanisms, is the likely slip mechanism. Our results indicate that in this case, contrary to what is usually assumed in models of soft-bedded glaciers, resistance to basal slip can be less than the ambient Coulomb yield strength of the till, owing to pore-pressure feedback that effectively weakens till near the glacier sole.

However, for this process to be a potentially important velocity-weakening mechanism a significant fraction of the 
bed that is in contact with ice must consist of particles sufficiently large to undergo rate-dependent ploughing. Particularly for fine-grained tills, the water layer at the bed surface (e.g. Brown and others, 1987; Alley, 1989; Tulaczyk, 1999) will tend to submerge a fraction of the bed area, over which there will be effectively no resistance to basal motion. Thus, a key question is whether rate-dependent ploughing is likely over a significant fraction of the remaining unsubmerged area of the bed. To explore this issue for the finegrained Des Moines Lobe till we note that, like some other basal tills, there is a power-law relationship between the number of grains of a given size class and grain size (Hooke and Iverson, 1995). This relationship allows the proportion of the unsubmerged fraction of the bed occupied by particles above a threshold size to be calculated as a function of waterlayer thickness and of only two parameters that describe the grain-size distribution: the power-law exponent (fractal dimension) and maximum grain size of the till (Iverson, 1999). In Figure 15 we consider two size thresholds, 2 and $10 \mathrm{~mm}$, above which rate-dependent ploughing will be expected for reasonable ranges of sliding speed and till diffusivity (Fig. 14). The fractal dimension of the Des Moines Lobe till is 2.96 (Hooyer and Iverson, 2002) and because the maximum grain size is difficult to measure or estimate we consider two quite different values, 0.1 and $1.0 \mathrm{~m}$. Even for water-layer thicknesses as small as $1 \mu \mathrm{m}, 25-55 \%$ of the bed area in contact with ice will be subject to velocity weakening (Fig. 15). Choosing a water-layer thickness of $0.1 \mathrm{~mm}$, equal to that inferred for Whillans Ice Stream (Engelhardt and Kamb, 1997), yields $40-77 \%$ of the bed area. Thus, it would appear that the bed area affected by this velocity-weakening mechanism can be significant. A potential effect of this weakening during glacier speed-up would be to progressively shift the downslope component of the glacier weight elsewhere, causing longitudinal and lateral stress gradients and ultimately further increasing the speed of the glacier.

Pervasive bed deformation has been commonly invoked as a mechanism for high glacial sediment fluxes (e.g. Alley, 1991, 2000; Jenson and others, 1995; Boulton, 1996; Dowdeswell and Siegert, 1999; Siegert and Dowdeswell, 2002). Our finding that ploughing resistance can decrease with increasing ploughing speed has clear implications for the bed-normal distribution of velocity in a soft bed: high rates of basal motion might create a weak till layer near the glacier sole where shear strain would be focused due to ploughing. Thus, a smaller thickness of the bed would be subjected to shear, with a potentially reduced sediment flux.

\subsection{Basal seismicity}

Velocity weakening plays a central role in explanations of rapid slip on crustal faults (e.g. Scholz, 2002, p. 82). If slip resistance on a fault decreases with slip velocity, then a force imbalance can develop that briefly causes acceleration of fault-bounding rocks sufficient to generate seismic waves. A force imbalance results because, if rocks loading a fault are sufficiently compliant elastically, slip resistance can decrease faster than the rate at which the driving stress decreases on the fault due to elastic relaxation of adjacent rocks. Thus, there is a mismatch between the rate at which slip resistance declines and the rate at which stress transfer to other parts of the fault occurs. This mismatch results in rock acceleration, followed by deceleration once driving and resisting stresses have become equal after sufficient relaxation of fault-bounding rocks (see fig. 2.16 in Scholz, 2002).

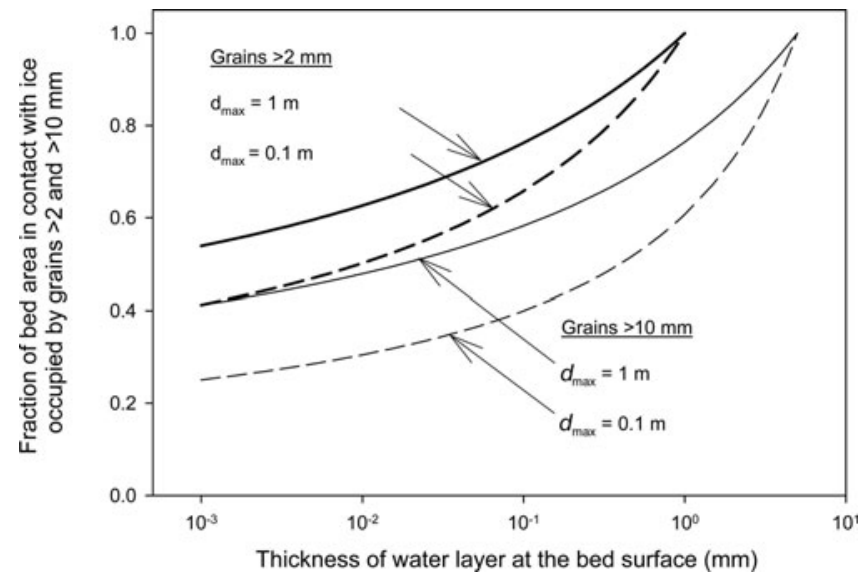

Fig. 15. Fractional area of the bed that is not submerged by the water layer occupied by grains larger than 2 and $10 \mathrm{~mm}$ in diameter, as a function of water-layer thickness, for the grain-size distribution of the Des Moines Lobe till. Grains 2 and $10 \mathrm{~mm}$ in diameter are sizes above which ploughing-induced velocity weakening is likely for common ranges of sliding speed and till diffusivity. The fractal dimension of the grain-size distribution is 2.96 (Hooyer and Iverson, 2002), and two different maximum grain sizes $\left(d_{\text {max }}\right)$ for the size distribution are assumed for each of the two size thresholds. The till porosity is assumed to be 0.35 .

Although processes responsible for glacier seismicity are difficult to isolate definitively (e.g. Deichmann and others, 2000; Ekström and others, 2006; Tsai and Ekström, 2007), at least some seismicity is clearly caused by basal-slip processes (Anandakrishnan and Bentley, 1993; Anandakrishnan and Alley, 1994, 1997). As part of a soft-bedded glacier speeds up, for whatever reason, it may exceed the transitional slip velocity (Fig. 14) required for widespread velocity weakening. Glaciers can behave elastically over periods of minutes to 1 day (Bahr and Rundle, 1996) and are elastically more compliant than crustal rocks. This compliance increases the likelihood of a brief force imbalance at the bed. Moreover, the extent of velocity weakening observed in this study is orders of magnitude greater than the fault-gouge velocity weakening sufficient to generate crustal earthquakes (Scholz, 2002, p. 85). In addition, in contrast to the velocity-weakening mechanism for a rigid bed (Schoof, 2004), weakening occurs immediately with an increase in slip velocity, so that it can conceivably occur at a rate that is higher than the rate at which stress can be transferred to other parts of the bed through elastic relaxation of ice. Thus, we view the velocity-weakening mechanism of this study as a viable candidate for enabling basal seismicity.

\section{CONCLUSIONS}

When particles that couple a glacier to a till bed plough, slip resistance can depend inversely on ploughing velocity. As ploughing velocity increases, progressively higher excess pore pressures are generated down-glacier from ploughing particles, weakening till there and decreasing ploughing resistance. In our experiments, steady-state ploughing resistance decreased by a factor of 3.0-6.6 with a six-fold increase in sliding speed (e.g. Fig. 6). Timescales of till compaction and pore-pressure diffusion depend on ploughing velocity, sizes of ploughing particles and till hydraulic 
diffusivity, and accurately predict the ranges of these variables under which velocity weakening occurs. These ranges are within those relevant to many soft-bedded, wetbased glaciers, although basal tills of sufficiently high hydraulic permeability, and hence diffusivity, will not be subject to this effect. Small excess pore pressures without velocity weakening in laboratory ploughmeter experiments (Rousselot and Fischer, 2007) resulted from the high diffusivity of the sediments used.

Existing models of ploughing fail to account for the observed pore-pressure feedback and velocity weakening, although those that assume Coulomb till behavior under either fully drained or undrained conditions can be adequate for specific ranges of ploughing-particle size, ploughing velocity and till diffusivity. The new ploughing model presented here accounts for the effect of excess pore pressure on till strength and seepage drag and provides an estimate of ploughing resistance within $3-38 \%$ of measured values. Velocity weakening at the surface of a soft bed by ploughing may help trigger fast glacier flow and inhibit deformation of the bed at depth. Velocity weakening is also a requirement for slip-induced basal seismicity.

\section{ACKNOWLEDGEMENTS}

We are grateful to B. Hubbard, S. Tulaczyk and an anonymous reviewer for comments that improved the paper. We also acknowledge J. Marchetti, formerly of the Electrical Engineering Machine Shop of the University of Minnesota, for his skilful fabrication of the ploughing insert for the ringshear device. We also thank D. Nelsen for helping with preliminary experiments. This work was supported by the US National Science Foundation: OPP-9725360. Publication was authorized by the Chief, Illinois State Geological Survey.

\section{REFERENCES}

Alley, R.B. 1989. Water-pressure coupling of sliding and bed deformation: II. Velocity-depth profiles. J. Glaciol., 35(119), 119-129.

Alley, R.B. 1991. Deforming-bed origin for southern Laurentide till sheets? J. Glaciol., 37(125), 67-76.

Alley, R.B. 2000. Continuity comes first: recent progress in understanding subglacial deformation. In Maltman, A.J., B. Hubbard and M.J. Hambrey, eds. Deformation of glacial materials. London, Geological Society, 171-179. (Special Publication 176.)

Anandakrishnan, S. and R.B. Alley. 1994. Ice Stream C, Antarctica, sticky spots detected by microearthquake monitoring. Ann. Glaciol., 20, 183-186.

Anandakrishnan, S. and R.B. Alley. 1997. Tidal forcing of basal seismicity of Ice Stream C, West Antarctica, observed far inland. J. Geophys. Res., 102(B7), 15,183-15,196.

Anandakrishnan, S. and C.R. Bentley. 1993. Micro-earthquakes beneath Ice Streams B and C, West Antarctica: observations and implications. J. Glaciol., 39(133), 455-462.

Bahr, D.B. and J.B. Rundle. 1996. Stick-slip mechanics at the bed of a glacier. Geophys. Res. Lett., 23(16), 2073-2076.

Blake, E.W., U.H. Fischer and G.K.C. Clarke. 1994. Direct measurement of sliding at the glacier bed. J. Glaciol., 40(136), 595-599.

Boulton, G.S. 1996. Theory of glacial erosion, transport and deposition as a consequence of subglacial sediment deformation. J. Glaciol., 42(140), 43-62.

Brown, N.E., B. Hallet and D.B. Booth. 1987. Rapid soft bed sliding of the Puget glacial lobe. J. Geophys. Res., 92(B9), 8985-8997.
Campanella, R.G., P.K. Robertson and D. Gillespie. 1983. Cone penetration testing in deltaic soils. Can. Geotech. J., 20(1), 23-35.

Christoffersen, P., J.A. Piotrowski and N.K. Larsen. 2005. Basal processes beneath an Arctic glacier and their geomorphic imprint after a surge, Elisebreen, Svalbard. Quat. Res., 64(2), 125-137.

Clark, P.U. and A.K. Hansel. 1989. Clast ploughing, lodgement and glacier sliding over a soft glacier bed. Boreas, 18(3), 201-207.

Clark, C.D., S.M. Tulaczyk, C.R. Stokes and M. Canals. 2003. A groove-ploughing theory for the production of mega-scale glacial lineations, and implications for ice-stream mechanics. J. Glaciol., 49(165), 240-256.

Clarke, G.K.C. 2005. Subglacial processes. Annu. Rev. Earth Planet. Sci., 33, 247-276.

Cohen, J. 1988. Statistical power analysis for the behavioral sciences. Second edition. Hillsdale, NJ, Lawrence Erlbaum Associates.

Das, B.M. 1998. Principles of geotechnical engineering. Fourth edition. Boston, MA, PWS Publishing.

Deichmann, N., J. Ansorge, F. Scherbaum, A. Aschwanden, F. Bernardi and G.H. Gudmundsson. 2000. Evidence for deep icequakes in an Alpine glacier. Ann. Glaciol., 31, 85-90.

Dowdeswell, J.A. and M.J. Siegert. 1999. Ice-sheet numerical modelling and marine geophysical measurements of glacierderived sedimentation on the Eurasian Arctic continental margins. Geol. Soc. Am. Bull., 111(2), 1080-1097.

Ekström, G., M. Nettles and V.C. Tsai. 2006. Seasonality and increasing frequency of Greenland glacial earthquakes. Science, 311(5768), 1756-1758

Engelhardt, H. and B. Kamb. 1997. Basal hydraulic system of a West Antarctic ice stream: constraints from borehole observations. J. Glaciol., 43(144), 207-230.

Engelhardt, H. and B. Kamb. 1998. Basal sliding of Ice Stream B, West Antarctica. J. Glaciol., 44(147), 223-230.

Finke, K.A., P.W. Mayne and R.A. Klopp. 2001. Piezocone penetration testing in Atlantic piedmont residuum. J. Geotech. Geoenviron. Eng., 127(1), 48-54

Finnie, I.M.S. and M.F. Randolph. 1994. Punch-through and liquefaction induced failure of shallow foundations on calcareous sediments. In Chryssostomidis, C., ed. BOSS '94. Proceedings of the 7 th International Conference on the Behaviour of Offshore Structures, Vol. 1. Oxford, Pergamon, 217-230.

Fischer, U.H. and G.K.C. Clarke. 1994. Ploughing of subglacial sediment. J. Glaciol., 40(134), 97-106.

Fischer, U.H., P.R. Porter, T. Schuler, A.J. Evans and G.H. Gudmundsson. 2001. Hydraulic and mechanical properties of glacial sediments beneath Unteraargletscher, Switzerland: implications for glacier basal motion. Hydrol. Process., 15(18), 3525-3540.

Fowler, A.C. 1981. A theoretical treatment of the sliding of glaciers in the absence of cavitation. Philos. Trans. R. Soc. London, Ser. A, 298(1445), 637-681.

Fowler, A.C. 1986. A sliding law for glaciers of constant viscosity in the presence of subglacial cavitation. Proc. R. Soc. London, Ser. A, 407(1832), 147-170.

Freeze, R.A. and J.A. Cherry. 1979. Groundwater. Englewood Cliffs, NJ, Prentice Hall.

Head, K.H. 1989. Soil technician's handbook. New York, etc., John Wiley and Sons.

Hooke, R.LeB. and N.R. Iverson. 1995. Grain-size distribution in deforming subglacial tills: role of grain fracture. Geology, 23(1), $57-60$.

Hooyer, T.S. and N.R. Iverson. 2000a. Clast-fabric development in a shearing granular material: implications for subglacial till and fault gouge. Geol. Soc. Am. Bull., 112(5), 683-692.

Hooyer, T.S. and N.R. Iverson. 2000b. Diffusive mixing between shearing granular layers: constraints on bed deformation from till contacts. J. Glaciol., 46(155), 641-651. 
Hooyer, T.S. and N.R. Iverson. 2002. Flow mechanism of the Des Moines lobe of the Laurentide ice sheet. J. Glaciol., 48(163), 575-586.

House, A.R., J.R.M.S. Oliveira and M.F. Randolph. 2001. Evaluating the coefficient of consolidation using penetration tests. Int. J. Phys. Model. Geotech., 1(3), 17-26.

Iverson, N.R. 1999. Coupling between a glacier and a soft bed. II. Model results. J. Glaciol., 45(149), 41-53.

Iverson, N.R. and T.S. Hooyer. 2004. Estimating the sliding velocity of a Pleistocene ice sheet from plowing structures in the geologic record. J. Geophys. Res., 109(F4), F04006. (10.1029/ 2004JF000132.)

Iverson, N.R., P. Jansson and R.LeB. Hooke. 1994. In-situ measurement of the strength of deforming subglacial till. J. Glaciol., 40(136), 497-503.

Iverson, N.R., B. Hanson, R.LeB. Hooke and P. Jansson. 1995. Flow mechanism of glaciers on soft beds. Science, 267(5194), $80-81$.

Iverson, N.R., T.S. Hooyer and R.LeB. Hooke. 1996. A laboratory study of sediment deformation: stress heterogeneity and grainsize evolution. Ann. Glaciol., 22, 167-175.

Iverson, N.R., R.W. Baker and T.S. Hooyer. 1997. A ring-shear device for the study of till deformation: tests on tills with contrasting clay contents. Quat. Sci. Rev., 16(9), 1057-1066.

Iverson, N.R., T.S. Hooyer and R.W. Baker. 1998. Ring-shear studies of till deformation: Coulomb-plastic behavior and distributed strain in glacier beds. J. Glaciol., 44(148), 634-642.

Iverson, N.R. and 6 others. 2003. Effects of basal debris on glacier flow. Science, 301(5629), 81-84.

Iverson, N.R. and 7 others. 2007. Soft-bed experiments beneath Engabreen, Norway: regelation infiltration, basal slip, and bed deformation. J. Glaciol., 53(182), 323-340.

Jenson, J.W., P.U. Clark, D.R. MacAyeal, C. Ho and J.C. Vela. 1995. Numerical modeling of advective transport of saturated deforming sediment beneath the Lake Michigan Lobe, Laurentide Ice Sheet. Geomorphology, 14(2), 157-166.

Jørgensen, F. and J.A. Piotrowski. 2003. Signature of the Baltic Ice Stream on Funen Island, Denmark during the Weichselian glaciation. Boreas, 32(1), 242-255.

Kamb, B. 1970. Sliding motion of glaciers: theory and observation. Rev. Geophys. Space Phys., 8(4), 673-728.

Kamb, B. 1991. Rheological nonlinearity and flow instability in the deforming bed mechanism of ice stream motion. J. Geophys. Res., 96(B10), 16,585-16,595.

Kim, K. 2005. Cone penetration test in clayey soil: rate effect and application to pile shaft resistance calculations. (PhD thesis, Purdue University.)

Koumoto, T. and K. Kaku. 1982. Three-dimensional analysis of static cone penetration into clay. In Verruijt, A., F.L. Beringen and E.H. de Leeuw, eds. Penetration testing. Rotterdam, A.A. Balkema, 635-640.

Krzyszkowski, D. 1994. Forms at the base of till units indicating deposition by lodgement and melt-out, with examples from the Wartanian tills near Belchatów, central Poland. Sediment. Geol., 91(1-4), 229-238.

Lambe, T.W. and R.V. Whitman. 1969. Soil mechanics. New York, etc., John Wiley and Sons.

Malyshev, M.V. and A.A. Lavisin. 1974. Certain results obtained in cone penetration of a sand base. In Broms, B.B., ed. Proceedings of the European Symposium on Penetration Testing, 5-7 June 1974, Stockholm, Sweden. Stockholm, National Swedish Building Research, 237-239.

Mitchell, J.K. and K. Soga. 2005. Fundamentals of soil behavior. Third edition. Hoboken, NJ, John Wiley and Sons.
Moore, P.L. 2002. A laboratory study of dilatant hardening: a mechanism for slow shear of granular materials. (MS thesis, lowa State University.)

Moore, P.L. and N.R. Iverson. 2002. Slow episodic shear of granular materials regulated by dilatant strengthening. Geology, 30(9), 843-846.

Nye, J.F. 1967. Theory of regelation. Philos. Mag., 16(144), $1249-1266$.

Nye, J.F. 1969. A calculation on the sliding of ice over a wavy surface using a Newtonian viscous approximation. Proc. R. Soc. London, Ser. A, 311(1506), 445-467.

Paterson, W.S.B. 1994. The physics of glaciers. Third edition. Oxford, etc., Elsevier.

Piotrowski, J.A., N.K. Larsen, J. Menzies and W. Wysota. 2006. Formation of subglacial till under transient bed conditions: deposition, deformation, and basal decoupling under a Weichselian ice sheet lobe, central Poland. Sedimentology, 53(1), 83-106.

Rousselot, M. 2006. A combined field and laboratory study of clast ploughing. (PhD thesis, ETH Zürich.)

Rousselot, M. and U.H. Fischer. 2005. Evidence for excess porewater pressure generated in subglacial sediment: implications for clast ploughing. Geophys. Res. Lett., 32(11), L11501. (10.1029/2005GL022642.)

Rousselot, M. and U.H. Fischer. 2007. A laboratory study of ploughing. J. Glaciol., 53(181), 225-231.

Scherer, R.P., C.M. Sjunneskog, N.R. Iverson and T.S. Hooyer. 2004. Assessing subglacial processes from diatom fragmentation patterns. Geology, 32(7), 557-560.

Scholz, C.H. 2002. The mechanics of earthquakes and faulting. Second edition. Cambridge, Cambridge University Press.

Schoof, C. 2004. The effect of cavitation on glacier sliding. Proc. $R$. Soc. London, Ser. A, 461(2055), 609-627.

Senneset, K. and N. Janbu. 1985. Shear strength parameters obtained from static cone penetration tests. In Chaney, R.C. and K.R. Demars, eds. Strength testing of marine sediments: laboratory and in-situ measurements. Philadelphia, PA, American Society for Testing and Materials, 41-54. (Special Technical Publication 883.)

Siegert, M.J. and J.A. Dowdeswell. 2002. Late Weichselian iceberg, surface-melt and sediment production from the Eurasian Ice Sheet: results from numerical ice-sheet modelling. Mar. Geol., 188(1-2), 109-127.

Thomason, J.F. and N.R. Iverson. 2006. Microfabric and microshear evolution in deformed till. Quat. Sci. Rev., 25(9-10), 1027-1038.

Tika, T.E., P.R. Vaughan and L.J. Lemos. 1996. Fast shearing of preexisting shear zones in soil. Géotechnique, 46(2), 197-233.

Truffer, M. and W.D. Harrison. 2006. In situ measurements of till deformation and water pressure. J. Glaciol., 52(177), 175-182.

Tsai, V.C. and G. Ekström. 2007. Analysis of glacial earthquakes. J. Geophys. Res., 112(F3), F03522. (10.1029/2006JF000596.)

Tulaczyk, S. 1999. Ice sliding over weak, fine-grained tills: dependence of ice-till interactions on till granulometry. In Mickelson, D.M. and J.W. Attig, eds. Glacial processes: past and present. Boulder, CO, Geological Society of America, 159-177. (Special Paper 337.)

Tulaczyk, S. 2006. Scale independence of till rheology. J. Glaciol., 52(178), 377-380.

Tulaczyk, S.M., B. Kamb and H.F. Engelhardt. 2000. Basal mechanics of Ice Stream B, West Antarctica. I. Till mechanics. J. Geophys. Res., 105(B1), 463-481.

Tulaczyk, S.M., R.P. Scherer and C.D. Clark. 2001. A ploughing model for the origin of weak tills beneath ice streams: a qualitative treatment. Quat. Int., 86(1), 59-70.

Weertman, J. 1964. The theory of glacier sliding. J. Glaciol., 5(39), 287-303. 